\title{
FAKTOR-FAKTOR YANG MEMPENGARUHI KINERJA USAHA MUSLIMPRENEUR DI KOTA BATAM
}

\author{
Mei Sumarni, Shinta Wahyu Hati \\ Prodi Administrasi Bisnis Terapan-Jurusan Manajemen Bisnis \\ Politeknik Negeri Batam \\ Email: shinta@polibatam.ac.id
}

\begin{abstract}
This study aims to determine what factors are considered Muslim entrepreneurs in determining the business performance of a Muslimpreneur in the city of Batam. Techniques of collecting data using questionare, observation, and documentation. Test the research instrument by using the validity and reliability analysis. Data analysis method used descriptive analysis and confirmatory factor analaisis (CFA). The result of the research shows 4 variables forming the business performance of a Muslimpreneur namely Human Resources, Marketing, Finance, and Production. While the most dominant factor considered by employers in determining the performance of a muslimpreneur in Batam City is the production and human resources with the value of variance of $0.23 \%$ and $1.45 \%$.
\end{abstract}

Keywords: Business Performance, Muslimpreneur, Batam

\section{Cara mencitasi:}

Sumarni, M \& Hati, S.W. (2019). Faktor-Faktor Yang Mempengaruhi Kinerja Usaha Muslimpreneur Di Kota Batam. Iqtishoduna: Jurnal Ekonomi dan Bisnis Islam. Vol 15 (1): 71-96.

\section{Pendahuluan}

Perekonomian negara Indonesia pernah mengalami goncangan besar yang disebabkan oleh krisis ekonomi pada tahun 1997 sampai 1998. Peristiwa tersebut telah memberikan dampak yang merugikan bagi kondisi perekonomian Indonesia pada saat itu, karena banyak perusahaan yang gulung tikar, perbankan hancur, pengangguran meningkat, kemiskinan meningkat. Sementara tahun 2008, dunia kembali dihadapkan krisis keuangan global yang mulai muncul bulan Agustus 2007, yaitu pada saat salah satu bank terbesar Perancis, BNP Paribas mengumumkan penghentian beberapa sekuritas yang bersangkutan dengan kredit perumahan berisiko tinggi Amerika Serikat (subprime mortgage). Ini menyebabkan gejolak besar bagi kehidupan ekonomi seluruh dunia, tak terkecuali Indonesia. Intensitas krisis semakin membesar akibat bangkrutnya bank investasi terbesar Amerika Serikat, Lehman Brothers yang diikuti oleh melemahnya keuangan yang semakin menurun di sejumlah lembaga keuangan berskala internasional di 
Mei Sumarni, Shinta Wahyu Hati

Amerika Serikat, Eropa, dan Jepang (Outlook Ekonomi Indonesia 2009-2014, Edisi Januari 2009).

Perekonomian Indonesia saat itu hampir semua lapisan masyarakat merasakan dampaknya tetapi ada pihak yang tetap stabil dengan adanya krisis ekonomi yaitu pengusaha, pengusaha tetap kokoh berdiri meskipun keadaan ekonomi sedang tidak stabil. Menurut Heflin (2010) dalam pentingnya profesi wirausaha di Indonesia, karena besarnya peran yang dimainkan oleh wirausaha di dalam mengatasi berbagai problematik nasional seperti masalah mengurangi angka kemiskinan, meningkatnya jumlah pengangguran, menurunnya tingkat pembelian, sulitnya penciptaan lapangan usaha dan lapangan kerja, serta peningkatan pertumbuhan ekonomi. Sehingga dalam keadaan kolaps nya ekonomi wirausaha masih tetap bertahan karena : 1) UMKM menghasilkan barang konsumsi dan jasa yang dekat dengan kebutuhan masyarakat; 2) faktor kedua yakni pelaku usaha UMKM umumnya memanfaatkan Sumber daya lokal, baik itu untuk sumber daya manusia, modal, bahan baku, hingga peralatan. Artinya, sebagian besar kebutuhan UMKM tidak mengandalkan barang impor; 3) faktor ketiga, umumnya bisnis UMKM tidak ditopang dana pinjaman dari bank, melainkan dari dana sendiri," menurut Rohmad, dalam paparan strategis CIDES: Dampak Kenaikan Harga BBM pada Sektor UKM di Indonesia, Jakarta, Rabu (28 Maret 2012).

Faktor tersebut menjadi landasan pilihan yang tepat menjadi wirausaha karena dengan menjadi wirausaha karena hidup lebih baik akan dapat kita capai, akan banyak memiliki waktu bersama keluarga, sumber penghasilan akan jauh lebih besar, tidak ada pilihan, ide bisa menjadi sumber penghasilan, bisa membantu orang banyak dan beramal Zimmerer et al. (2008) menyatakan bahwa kewirausahaan adalah suatu proses penerapan kreativitas dan inovasi dalam memecahkan persoalan dan menemukan peluang untuk memperbaiki usaha. Zimmerer et al. (2008) juga menyatakan bahwa wirausahawan adalah seseorang yang menciptakan bisnis baru dengan mengambil risiko dan ketidakpastian demi mencapai keuntungan serta pertumbuhan dengan cara mengidentifikasi peluang yang signifikan dan menggabungkan sumber daya yang diperlukan sehingga bisa dikapitalisasikan.

Lebih lanjut Zimmerer et al. (2008) menjelaskan bahwa Wirausahawan adalah orang yang menciptakan bisnis baru dengan mengambil resiko dan ketidakpastian demi mencapai keuntungan dan pertumbuhan dengan cara mengidentifikasi peluang dan menggabungkan sumber daya yang diperlukan untuk mendirikannya". Dengan demikian, bahwa wirausaha merupakan semangat, perilaku, kemampuan untuk memberikan tanggapan yang positif 
terhadap peluang yang memperoleh keuntungan untuk diri sendiri dan atau pelayanan yang lebih baik pada pelanggan/masyarakat; dengan selalu berusaha mencari melayani langganan lebih banyak dan lebih baik, serta menciptakan dan menyediakan produk yang lebih bermanfaat dan menerapkan cara kerja yang lebih efisien, melalui keberanian mengambil risiko, kreativitas, dan inovasi, serta kemampuan manajemen Suryani (2012).

Dampak dari adanya krisis ekonomi yang telah diceritakan sebelumnya juga dirasakan oleh negara tetangga seperti di Malaysia, Singapura. Namun negara-negara tersebut tidak terhenti kegiatan ekonominya karena krisis ekonomi. Menurut Mongid dan Notodihardjo (2011) dalam pengembangan daya saing UMKM di Malaysia dan Singapura: sebuah komparasi bahwa Pengembangan UMKM di Malaysia menjadi prioritas utama pemerintah sehingga komitmennya terlihat sangat kuat. Sehingga krisis ekonomi tersebut tidak berdampak signifikan terhadap perekonomian dari Malaysia. Singapore juga telah menerapkan sistem wirausaha sejak dini.

Mongid dan Notodihardjo (2011) mengemukakan bahwa entrepreneurship bukan sekedar teori, sudah tertanam dalam pemikiran anakanak muda Singapura, bahwa mereka adalah negara kecil dengan sumber daya alam yang tidak banyak sehingga membutuhkan kerjasama dengan negaranegara tetangga. Sehingga jika ingin bertahan hidup kita tidak mengharapkan pekerjaan dari orang lain, namun jadilah wirausaha jadikan semua orang di Singapura dan penduduk dunia (terutama negara-negara tetangga) sebagai konsumen setia. Sehingga wajar jika krisis ekonomi yang terjadi tidak berdampak drastis pada perekonomian Malaysia dan Singapore.

Jika kita melihat pada masa modern saat ini pemerintah telah terlihat fokus mendukung entrepreneur Indonesia,seperti presiden Joko Widodo (Jokowi) menyatakan ketertarikannya terhadap pengusaha atau entrepreneur di Indonesia. Presiden Jokowi memberikan perhatian serta dukungan kepada para wirausaha muda mandiri yang kreatif dan inovatif untuk ikut membangun perekonomian Indonesia menjadi lebih baik. (www. Sindonews.com: 2015).

Keseriusan dukungan pemerintah pada wirausaha juga dirasakan oleh masyarakat Batam, ketua Dinas Pariwisata Batam ibu Eni menyampaikan dalam wawancara di kantor Pemerintah Kota Batam beberapa waktu lalu bahwa program kerja dari dinas pariwisata saat ini sudah mengarah pada masyarakat ekonomi kreatif sebagai bentuk keseriusan pemerintah dalam mendukung kewirausahaan yang ada di Batam. Sunantri, Toni (2010) dalam analisis pengaruh kunjungan wisatawan yang menjadikan Batam sebagai kawasan pariwisata MICE, Batam sebagai kota yang letaknya strategis karena 
Mei Sumarni, Shinta Wahyu Hati

berdekatan dengan Singapura dan Malaysia salah satunya tujuan wisata dunia dapat dikembangkan sebagai gerbang wisata Indonesia.

Batam memiliki luas wilayah yaitu $3.990 \mathrm{~km} 2$ yang terdiri dari wilayah daratan 1.380, $85 \mathrm{~km} 2$, dan Luas wilayah lautan $2.950 \mathrm{~km} 2$. Dikembangkan oleh pemerintah RI menjadi beberapa daerah yaitu : daerah industri, perdagangan, jasa, alih kapal dan pariwisata. Sejak berdirinya Kotamadya Administratif Batam pada tanggal 24 Desember 1983, Batam terus mengalami perkembangan yang pesat. Sesuai data dari Dinas Kependudukan tercatat bahwa hasil sensus penduduk Batam selama periode 2010-2016 pertumbuhan penduduk Batam rata-rata sebesar 7,68 \%. Data Kependudukan Kota Batam per 31 Desember 2016 tercatat berjumlah 1.038.849 jiwa. Batam termasuk kota dengan Pertumbuhan Penduduk terpesat di Indonesia. Batam di Provinsi Kepulauan Riau, dipilih sebagai kota dengan pertumbuhan populasi tertingi di dunia oleh salah satu perusahaan konsultasi di Amerika Serikat yaitu Demographia. Dalam laporan tahunan Demographia World Urban Areas, Batam ditempatkan pada urutan pertama dengan tingkat pertumbuhan penduduk 7,4 persen per tahun (www. Suara.com : 2015)

Pertumbuhan ekonomi Batam sebesar rata-rata 10\% lebih besar dari pertumbuhan ekonomi Nasional (https://www.batamnews: 2016). Data dari Dinas Perindustrian, Perdagangan dan Energi Sumber Daya Mineral Batam tercatat bahwa dalam kurun waktu terhitung Januari 2016 sampai Desember 2016 telah terdapat 1.156 usaha yang telah didirikan dari berbagai macam sektor usaha di Batam. Data tersebut menunjukan bahwa kewirausahaan Batam 2016 mengalami kenaikan yang signifikan yaitu 10\% dari tahun sebelumnya. Data tersebut terlihat jelas potensi Batam sangat menjanjikan untuk pengembangan wirausaha Batam. Selain data potensi yang dimiliki oleh Batam, potensi lainnya terkait sumber daya di Batam juga sangat menjanjikan, apalagi dengan polemik tenaga kerja yang dilakukan perusahaan untuk pensiun dini, berakibat pada meningkatnya jumlah pengangguran di Batam, demo kenaikan UMK yang membuat investor lari dari Batam sehingga banyak perusahaan tutup karena tidak mampu memenuhi tuntutan upah tenaga kerja. Sehingga jika keadaan tersebut kita kelola untuk mengarahkan masyarakat menjadi wirausaha, akan tepat, efektif, dan efesien sehingga dapat mengangkat perekonomian masyarakat Batam.

Munculnya komunitas pendukung wirausaha di Batam seperti Tangan Di Atas (TDA), memberikan semangat pada para wirausaha apalagi ditambah dukungan dari pemerintah terkait pengembangan wirausaha membuat 
Faktor-Faktor Yang Mempengaruhi Kinerja Usaha...

wirausaha muda dan pemula lebih termotivasi melakukan pengembangan wirausaha di Batam.

Karakteristik wirausaha secara umum jika kita kaitkan dengan jumlah masyarakat muslim di Batam, juga memiliki karakteristik yang tidak jauh berbeda diantaranya: bekerja dengan bingkai taqwa, halal adalah prioritas utama, tidak berlebihan dalam segala hal, hubungan baik dengan Allah SWT adalah prioritas utama, mempraktekkan nilai moral yang tinggi, menjaga kepercayaan, terpusat pada kesejahteraan, berpengetahuan luas. Sebagai contoh masyarakat dan lingkungan (Faizal et al., 2013).

Dalam pandangan islam menjadi entreprenenur adalah salah satu teladan dari Rasullullah SAW. Seperti Nabi teladan kita Muhammad SAW sudah berwirausaha sejak beliau masih kecil dengan cara membeli barang dari suatu pasar. Aktivitas bisnis tersebut dilakukan dengan maksud untuk membantu perekonomian keluarga pamannya Abu Thalib. Dalam kegiatan bisnisnya tersebut, beliau bersama pamannya melakukan pejalanan dagang ke Syiria. Bisnis Nabi Muhammad SAW terus berkembang pesat hingga bertemu dengan Khadijah dan beliau menawarkan untuk bekerjasama dengan sistem bagi hasil. Selama bermitra dengan Khadijah, Nabi Muhammad SAW telah melakukan pejalanan bisnis hingga ke Habasyah (Ethopia), Syria dan Jorash. Setelah menikah dengan Khadijah, Nabi Muhammad SAW menjabat sebagai pimpinan sekaligus rekan usaha istrinya.

Kegiatan bisnis pada masa Nabi mengalami peningkatan yang sangat signifikan, hal tersebut dikarenakan para sahabat- sahabat Rasul terbuka pemikiran akan wirausaha dengan beberapa ayat dan hadist diantaranya: "Apabila telah ditunaikan shalat, maka bertebaranlah kamu di muka bumi, dan carilah karunia Allah, dan ingatlah Allah sebanyak-banyaknya agar kamu beruntung". (Q.S Al Jumu'ah, 62:10). "Sungguh seandainya salah seorang di antara kalian mengambil beberapa utas tali, kemudian pergi ke gunung kemudian kembali memikul seikat kayu bakar dan menjualnya, kemudian dengan hasil itu Allah mencukupkan kebutuhan hidupmu, itu lebih baik daripad meminta-minta kepada sesama manusia, baik mereka memberi maupun tidak" (H.R.Bukhari). Perhatikan olehmu, sesungguhnya perdagangan itu di dunia ini adalah sembilan dari sepuluh pintu rezeki" (H.R. Ahmad).

Rameli at al. (2015) menyatakan bahwa seorang Muslimpreneur harus memperhatikan strategi usaha untuk meningkatkan kualitas sehingga kinerja usaha akan lebih untuk kedepannya. Kinerja usaha terdiri dari produksi, keuangan, pemasaran dan SDM. Kinerja usaha Kinerja usaha diartikan sebagai kemampuan awal memulai usaha dan mempertahankan keberlangsungan usaha.

Kenaikan presentase wirausaha tidak terlepas dari karakteristik wirausaha. Muhammad (2014) dalam karakteristik wirausaha 
Mei Sumarni, Shinta Wahyu Hati

mengemukakan pendapatnya bahwa kewirausahaan memiliki 7 (tujuh) karakteristik : 1) kepemimpinan, 2) Inovasi, 3) Cara pengambilan keputusan, 4) Sikap tanggung jawab terhadap perubahan, 5) Bekerja ekonomis dan efisien, 6) Visi masa depan, 7) Sikap terhadap risiko.

Munculnya komunitas pendukung wirausaha di Batam, memberikan semangat pada para wirausaha apalagi ditambah dukungan dari pemerintah terkait pengembangan wirausaha membuat wirausaha muda dan pemula lebih termotivasi melakukan pengembangan wirausaha di Batam. Berdasarkan data yang diperoleh dari DISPERINDAG belum terlihat apakah para pengusaha Muslim di Kota Batam telah menjalankan faktor-faktor terkait kinerja usaha seorang Muslimpreneur. Sehingga menimbulkan pertanyaan besar terkait faktor-faktor yang berpengaruh terhadap kinerja penusaha muslim di Kota Batam.

Adapun rumusan masalah dalam penelitian ini adalah: 1). sejauhmana faktor produksi berpengaruh terhadap kinerja usaha Muslimpreneur di Kota Batam? ; 2) Sejauhmana faktor pemasaran berpengaruh terhadap kinerja usaha Muslimpreneur di Kota Batam?; 3) Sejauhmana faktor keuangan berpengaruh terhadap kinerja usaha Muslimpreneur di Kota Batam?; 4) Sejauhmana faktor Sumber daya manusia berpengaruh terhadap kinerja usaha Muslimpreneur di Kota Batam?. Sedangkan tujuan penelitian adalah : mengetahui sejauhmana faktor produksi berpengaruh terhadap kinerja usaha Muslimpreneur di Kota Batam; 2) mengetahui sejauhmana faktor pemasaran berpengaruh terhadap kinerja usaha Muslimpreneur di Kota Batam; 3) mengetahui sejauhmana faktor keuangan berpengaruh terhadap kinerja usaha Muslimpreneur di Kota Batam; 4) serta mengetahui sejauhmana faktor Sumber daya manusia berpengaruh terhadap kinerja usaha Muslimpreneur di Kota Batam.

\section{Kajian Pustaka \\ Produksi}

Menurut Faizal at al. (2013) menjelaskan produksi adalah suatu proses mengubah kombinasi berbagai input menjadi output. Disebutkan produksi terdiri dari: tipe produk, memenuhi prinsip islam, menghasilkan produk yang halal. Adiwarman (2007) menjelaskan produksi adalah memberikan pemahan tentang perilaku perusahaan dalam membeli dan menggunakan masukan untuk menjualnya kembali.

\section{Pemasaran}

Kotler dan Amstrong (2008) menjelaskan pemasaran adalah kegiatan social dan sebuah pengaturan untuk mendapatkan apa yang diinginkan 
dengan membuat suatu produk baru dengan nominal tertentu. pemasaran adalah sebuah proses managerial yang orang orang didalamnya mendapatkan apa yang mereka inginkan melalui pertukaran dan nilai yang ditawarkan.

\section{Keuangan}

Keuangan dijelaskan oleh David (2011) adalah kondisi keuangan dianggap sebagai salah satu ukuran terbaik untuk posisi yang kompetitif. Menentukan ukuran kekuatan dan kelemahan keuangan suatu oranisasi sangat penting dalam sebuah kegiatan usaha. Sedangkan menurut Ridwan (2003) keuangan adalah ilmu dan seni yang mengelola keuangan yang mempengaruhi kehidupan setiap orang atau individu dan setiap organisasi

\section{Sumber Daya Manusia}

Dijelaskan oleh Mathis dan Jackson (2006) sumber daya manusia adalah rancangan sistem formal yang memastikan aplikasi bakat manusia secara efektif dan efesien guna mencapai tujuan organisasi. Dijelaskan kembali oleh Dessler (2014) Manajemen sumber daya manusia adalah kebijakan dan praktek di dalam menggerakan sumber daya manusia atau aspek-aspek terkait posisi manajemen di dalam sumber daya manusia yang mencakup kegiatan perekrutaan, penyaringan, pelatihan, pemberian penghargaan dan penilaian

\section{Kinerja Usaha}

Istilah kinerja berasal dari job performance atau actual performance (prestasi kerja atau prestasi sesungguhnya yang dicapai oleh seseorang), atau juga hasil kerja secara kualitas dan kuantitas yang ingin dicapai oleh seorang pegawai dalam melaksanakan tugasnya sesuai dengan tanggung jawab yang diberikan kepadanya (Mangkunegara, 2010).

Menurut Hasibuan (2010) menjelaskan bahwa, kinerja merupakan hasil kerja yang dicapai seseorang dalam melaksanakan tugas-tugas yang dibebankan kepadanya.Didasarkan atas kecakapan, pengalaman, kesungguhan serta waktu. Sawir dalam Hati (2015), kinerja keuangan merupakan suatu proses atau perangkat proses untuk mengetahui kondisi keuangan perusahaan, dengan cara pengambilan keputusan secara rasioanal dengan menggunakan alat-alat analisis tertentu.

\section{Kerangka Pemikiran}

Mengacu pada Faizal at al. (2013) kinerja usaha terdiri dari empat faktor yaitu: produksi, pemasaran, keuangan, dan sumber daya manusia. Kerangka pemikiran dari penelitian ini adalah sebagai berikut: 
Mei Sumarni, Shinta Wahyu Hati

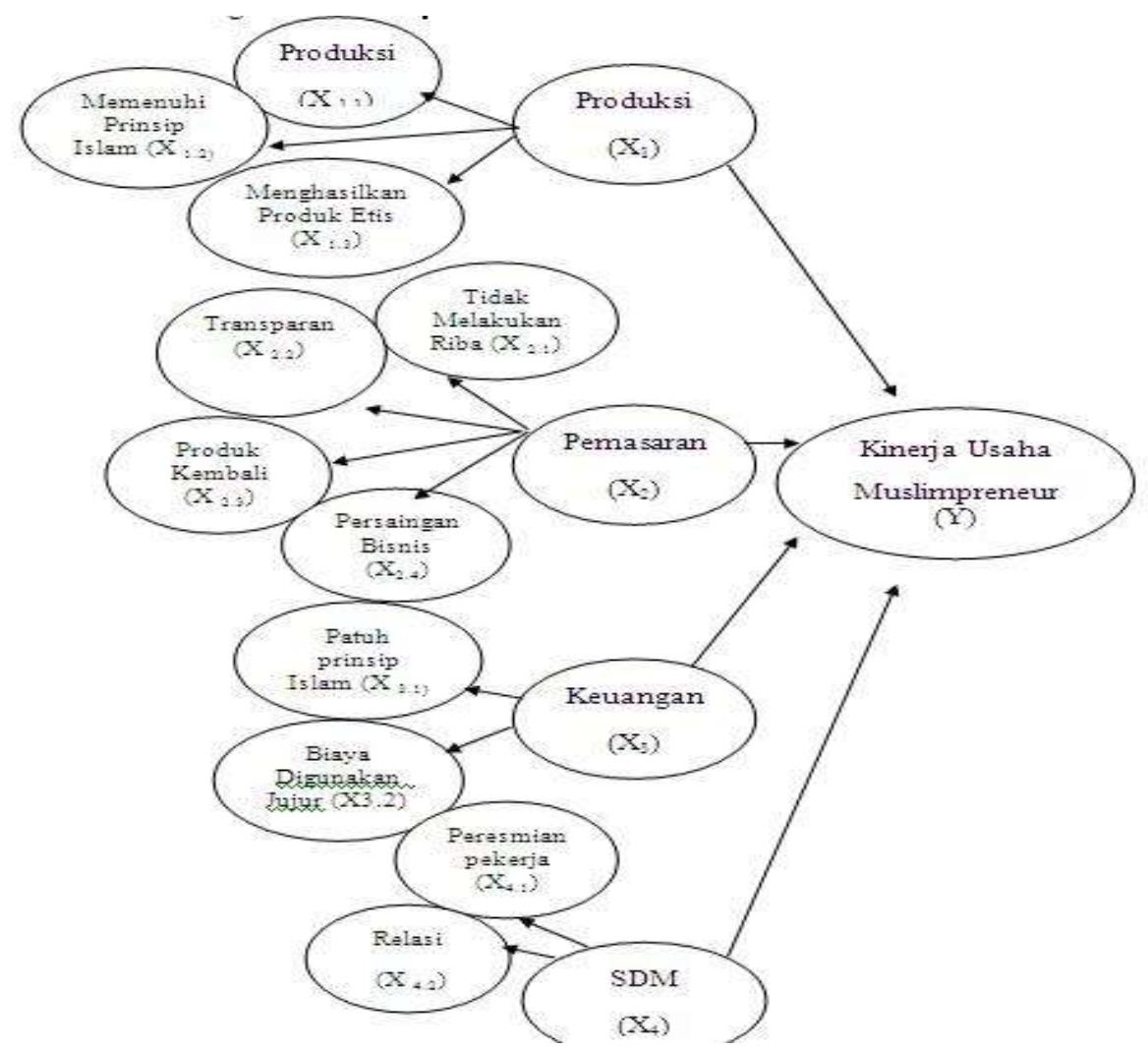

Gambar 1. Kerangka Pemikiran

\section{Metode Penelitian}

\section{Desain Penelitian}

Rancangan penelitian menggunakan pendekatan eksplanatori (Explanatory Research), merupakan penelitian yang menjelaskan hubungan kausal antara variabel penelitian dengan pengujian hipotesis. Pendekatan yang dipakai dalam penelitian ini adalah metode survei atau penelitian yang dilakukan untuk memperoleh fakta-fakta mengenai fenomena-fenomena yang ada di dalam obyek penelitian dan mencari keterangan secara aktual dan sistematis.

\section{Operasionalisasi Variabel}

Penelitian ini menggunakan variabel independen atau eksogen yaitu variabel yang mempengaruhi atau menjadi penyebab perubahan atau timbulnya variabel dependen. Variabel eksogen dalam peneltian ini adalah kinerja usaha Muslipreneur (X1): Produksi, pemasaran, keuangan, dan sumber daya manusia. Variabel dependen atau endogen adalah variabel yang mempengaruhi atau menjadi akibat adanya variabel independen variabel endogen dalam penelitian ini adalah Muslimpreneur. 
Faktor-Faktor Yang Mempengaruhi Kinerja Usaha...

Definisi operasional masing-masing variabel dan infikatornya sebagai berikut: Produksi (X1), dalam konsep ini adalah suatu proses mengubah kombinasi berbagai input menjadi output. Dengan indikator: sumber bahan baku halal, alat yang digunakan halal, melengkapi konsep halal, memiliki nilai ibadah kepada Allah, layak dan kompetitif, kegiatan tidak merugikan orang lain, konsep kebutuhan dan prioritas, tidak melakukan kegiatan yang menyimpang dari islam, menjaga kebersihan sesuai standart prosedur (Rameli et al., 2015).

Pemasaran (X2) Kotler menjelaskan pemasaran adalah kegiatan sosial dan sebuah pengaturan yang dikerjakan oleh individu atau kelompok agar mendapatkan apa yang diinginkan dengan membuat sebuah produk lalu menemukan dengan nominal tertentu kepada pihak lain. Maka indikator yang di ukur adalah: tidak monopoli, tidak manipulative, harga sesuai, tidak memaksa pelanggan, menggunakan model yang diperbolehkan oleh islam, menggunakan konsep khiyar islam, meningkatkan kualitas produk, tidak memfitnah pesaing, menjaga etika moral dengan orang lain.

Keuangan (X3) kondisi keuangan dianggap sebagai salah satu ukuran terbaik untuk terbaik untuk posisi kompetitif dan daya tarik keseluruhan usaha. Menentukan kekurangan dan kelemahan keuangan suatu organisasi sangat penting dalam rangka merumuskan strategi yang efektif (David, 2011). Maka indikator yang diukur adalah: berniat baik dalam transaksi keuangan, tidak melibatkan unsur riba, menggunakan cara yang jujur seperti dalam pengajuan permohonan dalam transaksi, menggunakan cara yang jujur dalam kegiatan transaksi seperti pengajuan dana secara trasparan, jujur terpercaya baik individu maupun lembaga, pengeluaran secara benar seperti untuk bonus dan penghargaan kepda karyawan, tidak melakukan pemborosan dana

Sumber Daya Manusia (X4) Matchis dan Jckson (2006) mengatakan sumber daya manusia adalah rancangan sistem formal dalam sebuah organisasi untuk memastikan aplikasi bakat manusia secara efektif dan efesien guna mencapai tujuan organisasi. Maka indkator yang diukur adalah: memperhatikan karyawan, bersikap adil dan setara, menganggap karyawan sebagai aseet lebih berharga dari sekedar tenaga kerja, hubungan yang adil dengan karyawan

\section{Populasi dan Sampel}

Populasi dalam penelitian ini adalah pengusaha muslim di Kota Batam. Sampel merupakan bagian dari populasi yang ingin diteliti oleh peneliti. Menurut Sugiyono (2011) sampel adalah bagian dari jumlah dan karakteristik yang dimiliki oleh populasi tersebut. Teknik pengambilan sampel sampel penulis menggunakan metode purposive sampling. Menurut Sugiyono (2011) 
Mei Sumarni, Shinta Wahyu Hati

purposive sampling adalah teknik penentuan sampel dengan pertimbangan tertentu. Kriteria sampel dalam penelitian ini yaitu pengusaha muslim yang sudah menjalankan usahanya dan sudah memiliki badan hukum.

Dari keseluruhan jumlah populasi didapatkan data bahwa pengusaha muslim berjumlah 110. Dengan cara berpedoman parameter pada ukuran sampel sebesar 5-10 kali parameter yang ada. Dalam penelitian ini terdapat 11 parameter yang diestimasi, sehingga diperlukan sampel sebesar 55-110 orang. Atas pertimbangan waktu dan biaya, dan kebutuhan data yang sesuai dengan analisis faktor, maka jumlah sampel dalam penelitian ini ditetapkan 110 sampel, dengan taraf signifikasi 5\%.

Tabel 1. Jumlah Responden

\begin{tabular}{|c|c|c|}
\hline No & $\begin{array}{c}\text { Nama } \\
\text { Daerah }\end{array}$ & $\begin{array}{l}\text { Jumlah } \\
\text { Sampel }\end{array}$ \\
\hline 1 & Batam Kota & 11 \\
\hline 2 & Batu Aji & 9 \\
\hline 3 & Batu Ampar & 10 \\
\hline 4 & Belakang Padang & 8 \\
\hline 5 & Bengkong & 11 \\
\hline 6 & Kecamatan Bulan & 8 \\
\hline 7 & Kecamatan Galang & 11 \\
\hline 8 & Lubuk Baja & 9 \\
\hline 9 & Sekupang & 9 \\
\hline 10 & Nongsa & 8 \\
\hline 11 & Sagulung & 10 \\
\hline \multirow[t]{2}{*}{12} & Kecamatan Sei & 6 \\
\hline & Total & 110 \\
\hline
\end{tabular}

\section{Analisis Data}

\section{Análisis Statistik Deskriptif}

Analisis statistik deskriptif digunakan untuk memberikan pemahaman tentang situasi yang terjadi atau berlaku karyawan di perusahaan.

\section{Analisis Faktor}

Pengujian validitas dilakukan dengan menggunakan analisis faktor yang merujuk pada hasil perhitungan Keiser-Meyer Olkin (KMO) Measure of Sampling Adequacy. Perhitungan dilakukan dengan bantuan program SPSS versi 20.0. Kriteria kecukupan nilai KMO adalah lebih dari 0,5, sehingga item yang memiliki nilai KMO kurang dari 0,5 direduksi atau dihilangkan, yaitu dengan menghilangkan item pernyataan yang memiliki nilai terkecil, dalam hal ini dapat dilihat pada Anti Image Correlation.

Langkah berikutnya dalam analisis faktor konfirmatori adalah menjelaskan component matrix. Selanjutnya Rotated Component Matrix 
Faktor-Faktor Yang Mempengaruhi Kinerja Usaha...

merupakan hasil rotasi dari component matrix. Hal ini bertujuan untuk memperlihatkan distribusi variabel yang jelas dan nyata dibandingkan dengan jika tidak dilakukan rotasi.

Setelah melakukan factoring dan rotasi, langkah selanjutnya adalah menginterprestasikan faktor yang terbentuk. Hal ini dilakukan agar bisa mewakili variabel-variabel anggota faktor terbentuk.

Tabel 2. Klasifikasi Nilai KMO

\begin{tabular}{cl}
\hline Ukuran KMO & \multicolumn{1}{c}{ Rekomendasi } \\
\hline$\geq 0,90$ & Sangat Baik (Marvelous) \\
\hline $0,80-0,89$ & Berguna (Meritorius) \\
\hline $0,70-0,79$ & Biasa (Middling) \\
\hline $0,60-0,69$ & Cukup (Mediocre) \\
\hline $0,50-0,59$ & Kurang (Miserable) \\
\hline$\leq 0,50$ & Tidak Diterima (Unacceptabel)
\end{tabular}

Nilai KMO bervariasi dari 0 sampai dengan 1. Pada tabel diatas ukuran nilai KMO memiliki rekomendasi masing-masing ukuran KMO $\leq 0,50$ memiliki rekomendasi tidak diterima (Unacceptabel).

\section{Hasil Penelitian Dan Pembahasan \\ Gambaran Wirausaha Kota Batam}

Berdasarkan data dari DISPERINDAG dalam kurun waktu tiga bulan saja tercatatat 211 wirausaha yang mendaftarkan diri ke DISPERINDAG guna mendapatkan izin usaha dari pemerintah. Dari uraian tersebut dapat diperkirakan sejauh mana wirausaha diterima oleh masyarakat. Selain itu wirausaha di Batam didominasi dengan para penjual makanan, oleh-oleh, hasil kerajinan, souvenir dan masih banyak usaha jasa serta lainnya.

Batam dikenal sebagai kota pariwisata, menyajikan aneka bentuk sarana pariwisata yaitu wisata laut dan pantai, wisata seni dan budaya, wisata belanja, wisata ekonomi dan konferensi, serta wisata kemanusiaan. Ditambah lagi dengan dukungan tersedianya fasilitas hotel dan resort dengan standart berkelas internasional serta pariwisata yang disusun dalam Kalender kegiatan Kota Batam sehingga diharapkan dapat menjamin kenyamanan dan kepuasan wisata domestik maupun mancanegara dalam berkunjung ke kota Batam.

\section{Gambaran Muslimpreneur dan UMKM Kota Batam}

Menjadi seorang wirausaha mendatangkan keuntungan tersendiri bagi wirausaha dalam memenuhi berbagai macam kebutuhan pelanggan, mulai dari kebutuhan sandang, pangan, papan. Seorang wirausaha juga membuka 
Mei Sumarni, Shinta Wahyu Hati

lapangan pekerjaan bagi penduduk lain yang belum memiliki pekerjaan. Dari langkah awal saja seorang wirausaha sudah membantu sesama sehingga bermanfaat bagi orang lain. Karena sebagai makluk sosial kita tidaklah dapat hidup seorang diri, seperti disebutkan dalam Al-quran yang artinya "Jika kalian berbuat baik, sesungguhnya kalian berbuat baik bagi diri kalian sendiri" (QS. Al-Isra:7).

Selain bermanfaat untuk orang lain, ternyata jelas bahwa berbuat baik kepada orang lain ternyata sama saja kita berbuat baik bagi diri kita sendiri. Dalam penjelasan lainnya disebutkan manfaat silaturahmi dalam H.R. Bukhari

"Barangsiapa yang senang untuk dilapangkan rizkinya dan diakhirkan ajalnya (dipanjangkan umurnya), maka hendaklah ia menyambung (tali) silaturahim." (H.R. Bukhari). Dalam sabda Abu Hurairah, sabda Rasulullah yang lain "Barangsiapa yang beriman kepada Allah dan hari akhir, hendaklah bersilaturahmi" (Muttafaqun 'alaihi)

Selain bermanfaat membantu orang lain mendapatkan pekerjaan, kita juga mengamalkan apa yang Rasulullah SAW ajarkan. Rasulullah sudah mulai berniaga sejak beliau belia bersama pamannya Abu Thalib.

Dikota Batam jumlah penduduk Muslim Batam menempati urutan pertama sebanyak 71,33\% berdasarkan data dari Badan Pusat Statistik Kota Batam 2016. Dengan mayoran muslim ternyata data dari DISPERINDAG Kota Batam menyebutkan memang mayoritas pengusaha di Kota Batam muslim. Tercatat pada Bulan November 2016 sampai Desember 2016 sebanyak 62 usaha Muslim mendaftarkan diri ke DISPERINDAG untuk mendapatkan nomor izin usaha. Sampai Desember 2016 data dari DISPERINDAG mengatakn jumlah total pengusaha mmuslim di Kota Batam sebanyak 1.125 pengusaha. Terbagi atas usaha Jasa, olahan makana, pusat oleh-oleh, maufakturing dan masih banyak lainnya.

\section{Muslimpreneur Berdasarkan Usia}

\section{Usia}

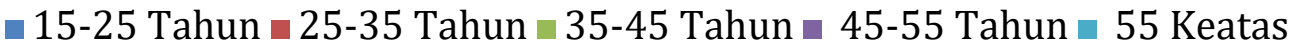

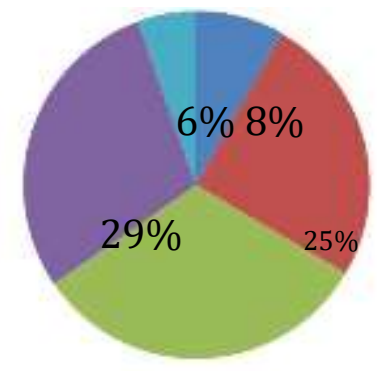

Gambar 2. Usia Muslimpreneur

82 | IQTISHODUNA Vol. 15 No. 1 Tahun 2019

http://ejournal.uin-malang.ac.id/index.php/ekonomi 
Faktor-Faktor Yang Mempengaruhi Kinerja Usaha...

Presentase paling tinggi sebsar 31,8\% pada kelompok usia 35-45 tahun. usia tersebut adalah usia produktif seorang. Mengapa usia tersebut dikatakan produktif karena pada usia tersebut seorang individu masih memiliki tenaga yang fit, bebas bergerak, bebas meekspresikan apapun hal karena masih ditunjang dengan kemampuan fisik yang kuat. Usia tersebut dikatakan produktif karena ketika bergerak akan menghasilkan hal yang positif hal yang bermanfaat bagi lingkungan sekitar. Sehingga dari hasil analisis yang disebarkan pada para responden yaitu para Muslimpreneur di Kota Batam memiliki usia yang produktif yaitu berkisar 35-45 tahun.

Frekuensi tertinggi untuk karakteristik jenis kelamin pada perempuan. Sebesar 53\% dengan frekuensi 58 responden. Alasan mengapa perempuan lebih dominan dalam menjadi seorang wirausaha khususnya di Kota Batam bisa terlihat dari keadaan Kota Batam. Kota batam merupakan kota Industri yang tentunya banyak pendatang dari luar pulau Batam yang mengadu nasib di Kota Industri ini. Dengan banyaknya pendatang ternyata tidak dibarengi dengan jumlah lapangan pekerjaan yang ada dikota Batam, selain itu kebijakan dari pemerintah Kota Batam sendiri terkait usia produktif perempuan bekerja adalah berkisar usia 18-24 tahun.

\section{Muslimpreneur Berdasarkan Jenis Kelamin}

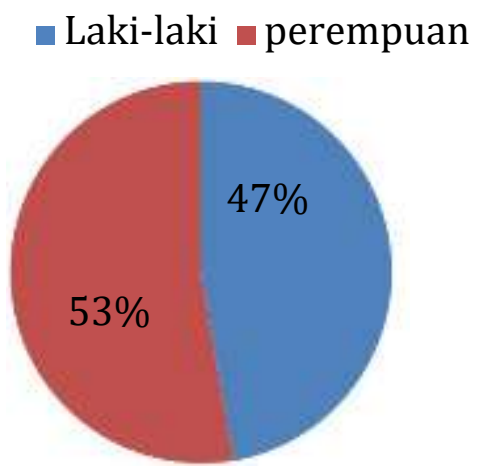

\section{Gambar 3. Jenis Kelamin Muslimpreneur}

Hal tersebut tentunya sangat berdampak pada jumlah pengangguran terutama wanita karena perusahaan sebelumnya banyak menyerap tenaga kerja perempuan. Sehingga dengan dikeluarkannya peraturan tentang kebijakan usia produktif, para perempuan yang usia sudah melampui usia produktif harus pulang kerumah karena tidak lagi memenuhi peryaratan dari perusahaan. Selain hal tersebut kebutuhan akan semakin naik karena jelas dengan tidak bekerjanya perempuan jumlah pemasukan ekonomi dalam 
Mei Sumarni, Shinta Wahyu Hati

keluarga tidak akan cukup karena awalnya dua belah pihak laki-laki dan perempuan bekerja.

Tidak adanya keharusan ataupun larangan perempuan membantu pemasukan keluarga, sehingga para perempuan mulai membuat hal-hal yang bisa menghasilkan pundi-pundi rezeki untuk membantu suami sekaligus memanfaat waktu luang karena tidak lagi bekerja. Sehingga sangatlah wajar jika pengusaha di Kota Batam didominasi oleh perempuan.

\section{Muslimpreneur Berdasarkan Tempat Tinggal}

Kota Batam merupakan pengusaha produktif. Hal ini dikarenakan usia pengusaha muslim lebih banyak dengan usia 35-45 tahun sehingga bisa dikatakan dominan berusia produktif.

Tabel 3. Tempat Tinggal Muslimpreneur

\begin{tabular}{cccc}
\hline No & Kecamatan & Frekuensi & Presentase \\
& & & (\%) \\
\hline 1 & Batam Kota & 12 & 11,0 \\
2 & Batu Aji & 9 & 8,2 \\
3 & Batu Ampar & 10 & 9,1 \\
4 & Belakang Padang & 8 & 7,3 \\
5 & Bengkong & 11 & 10,0 \\
6 & Bulan & 8 & 7,3 \\
7 & Galang & 11 & 10,0 \\
8 & Lubuk Baja & 9 & 8,2 \\
9 & Sekupang & 9 & 8,2 \\
10 & Nongsa & 8 & 7,3 \\
11 & Sagulung & 10 & 9,1 \\
12 & Sei & 6 & 5,4 \\
& Total & $\mathbf{1 1 0}$ & $\mathbf{1 0 0 , 0}$ \\
\hline
\end{tabular}

Responden berdasarkan keseluruhan terbagi menjadi 12 kelurahan. Kelompok responden terbanyak berada pada kelurahan Batam Kota yaitu sebanyak 12 responden (11,0\%). Peringkat kedua berada di kelurahan Bengkong(10,0\%) dan Kecamatan Galang (10,0\%). Disusul kemudian oleh posisi ketiga yaitu batu Aji (9\%), Lubuk Baja (8,2\%) serta Sekupang. Alasan mengapa Batam Kota menjadi daerah dengan frekuensi terbesar karena daerah Batam Kota merupakan daerah Pusat di Batam. sehingga akan sangat wajar jika kegiatan lebih banyak pada daerah Batam Centre daripada daerah lainnya. Karena semua kegiatan pemerintahan serta objek objek besar di batam seperti Alun-alun Batam, kegiatan pemerintah kota biasa dilakukan di 
Faktor-Faktor Yang Mempengaruhi Kinerja Usaha...

daerah Batam Kota. Sehingga jelas hal tersebut sangat berpengaruh terhadap jumlah responden pengusaha yang ada di Kota Batam.

\section{Muslimpreneur Berdasarkan Pendidikan}

Tabel 4. Tempat Tinggal Muslimpreneur

\begin{tabular}{llcc}
\hline No & $\begin{array}{c}\text { Pendidikan } \\
\text { Terakhir }\end{array}$ & Frekuensi & Persentase \\
\hline 1 & SD/sederajat & 7 & 6,4 \\
2 & SLTP/sederajat & 16 & 14,5 \\
3 & SLTA/sederajat & 44 & 40,0 \\
4 & Diploma & 20 & 18,2 \\
5 & S1/S2 & 23 & 20,9 \\
& Total & $\mathbf{1 1 0}$ & $\mathbf{1 0 0 , 0}$ \\
\hline
\end{tabular}

Karakteristik pendidikan terakhir. Berdasarkan data pada tabel, dapat diketahui bahwa total jumlah responden 110, responden dengan pendidikan terakhir yang lebih dominan yaitu SLTA/ sederajat sebanyak 44 responden dengan presentase sebesar 40\%. Selanjutnya di ditempati oleh lulusan S1/S2 sebanyak 20,9\%. Alasan mengapa lulusan SMA Sederajat lebih banyak karena Batam merupakan daerah industry yang tentunya menyerap banyak sekali tenaga kerja. Lulusan SMK adalah usia produktif dalam kebijakan perusahaan, setelah mereka habis kontrak tentu perusahaan tidak akan meperpanjang para karyawan yang usianya sudah tidak lagi produktif. Para lulusan SMA sederajat memilih bekerja dan tidak melanjutkan sekolahnya karena kebanyak faktor ekonomi keluarga, mereka lebih memilih bekerja untuk membantu kedua orang tua dan memperbaiki perekonomian keluarga. Setelah masa kontrak kerja habis tentunya mereka kembali memutar strategi bagimana bisa tetap mendaptkan pundi-pundi keuntungan. Dan hal tersebut yang menjadi landasan mengapa jumlah lulusan SMA sederajat menempati urutan pertama. Setelah tidak lagi bekerja mereka mencoba peruntungan baru dnegan mulai menjadi seorang wirausaha.

Muslimpreneur Lama Menjalankan Usaha

Tabel 5. Lamanya Menjalankan Usaha

\begin{tabular}{cccc}
\hline No & $\begin{array}{c}\text { Lama } \\
\text { Menjalankan } \\
\text { usaha }\end{array}$ & Frekuensi & Presentase \\
\hline 1 & $<3$ Tahun & 14 & 12,7 \\
2 & 3-5 Tahun & 51 & 46,4 \\
3 & $>5$ Tahun & 45 & 40,9 \\
Total & & $\mathbf{1 1 0}$ & $\mathbf{1 0 0 , 0}$ \\
\hline
\end{tabular}


Mei Sumarni, Shinta Wahyu Hati

Berdasarkan data pada Tabel 5 dapat diketahui bahwa total jumlah responden 110. Rata-rata masyarakat Batam menjalankan usaha selama 3-5 tahun. Dengan presentase $46,4 \%$. Hal tersebut sangat sesuai jika kita melihat dari usia yang memiliki presentase tertinggi, sehingga tentu akan mempengaruhi lama usaha yang dijalankan. Karena kebanyak pengusaha di Batam masih dalam usia Produktif sehingga usaha yang dijalankan belum terlalu lama, yaitu rata-rata 3-5 tahun.

Adalah pengusaha muda yang masih mencoba untuk survive dalam dunia wirausaha. Untuk selanjutnya posisi lama usaha ditempati oleh pengusaha $>5$ tahun. Adalah para pengusaha yang telah memulai menjadi wirausaha saat Batam masih sangat ramai dengan industry asing, karena sampai saat ini perusahaan asing yang berada diBatam sudah tidak sebanyak dulu. Sehingga hal tersebut berpengaruh terhadap berbagai macam aspek termasuk aspek lama usaha yang dijalankan oleh seorang wirausaha.

\section{Muslimprenenur Berdasarkan Jenis Usaha}

Tabel 6. Berdasarkan Jenis Usaha

\begin{tabular}{cccc}
\hline No & Jenis Usaha & Frekuensi & Presentase \\
\hline 1 & Pedagang & 36 & 32,7 \\
2 & Pengolahan & 17 & 15,5 \\
3 & Jasa & 33 & 30,0 \\
4 & Budidaya & 22 & 20,0 \\
5 & Lainnya & 2 & 1,8 \\
Total & & 110 & 100,0 \\
\hline
\end{tabular}

Berdasarkan Tabel diatas tentang karakteristik responden berdasarkan Jenis Usaha, jenis usaha pedagang dari 110 responden menempati urutan pertama. Dengan presentase $32,7 \%$ dan frekuensi 36 responden. Selanjutnya di tempati oleh jenis usaha jasa dengan besar presentase $30,0 \%$.

\section{Muslimpreneur Berdasarkan Badan Usaha}

Tabel 7. Berdasarkan Badan Usaha

\begin{tabular}{cccc}
\hline No & Badan Usaha & Frekuensi & Presentase \\
\hline 1 & CV & 40 & 36,3 \\
2 & UD & 42 & 38,1 \\
3 & Firma & 8 & 7,2 \\
4 & PT & 11 & 10.0 \\
5 & Koperasi & 6 & 5,4 \\
6 & Lainnya & 3 & 2,72 \\
Total & & 110 & 100,0 \\
\hline
\end{tabular}

Sumber : Olah data SPSS 20

86 | IQTISHODUNA Vol. 15 No. 1 Tahun 2019

http://ejournal.uin-malang.ac.id/index.php/ekonomi 
Faktor-Faktor Yang Mempengaruhi Kinerja Usaha...

Berdasarkan Tabel diketahui jumlah badan usaha yang tertinggi dari 110 responden adalah badan usaha bentuk UD. Unit dagang adalah badan usaha yang sesuai dengan masyarakayt karena mudah kepengurusan perizinannya. Sehingga memudahkan masyarakat untuk membuka usaha dengan legalitas yang resmi.

\section{Muslimpreneur Berdasarkan Pesaing}

Tabel 8. Berdasarkan Pesaing

\begin{tabular}{|c|c|c|c|}
\hline No & Pesaing & Frekuensi & Persentase \\
\hline 1 & Ya & 107 & 97,3 \\
\hline 2 & Tidak & 3 & 2,7 \\
\hline & Total & 110 & 100,0 \\
\hline
\end{tabular}

Berdasarkan data pada Tabel 8 dapat diketahui bahwa jumlah responden sebanyak 110 pengusaha. Dari hasil kuisoner terlihat 97,3\% pengusaha mengatakan memiliki pesaing dalam menjalankan usahanya, dan hanya 3\% yang mengatakan tidak memiliki pesaing.

\section{Muslimpreneur Berdasarkan Kerjasama dengan Pengusaha Muslim}

\section{Tabel 9. Berdasarkan Kerjasama}

\begin{tabular}{clll} 
& \multicolumn{1}{c}{$\begin{array}{l}\text { Kerjsama } \\
\text { Pengusaha } \\
\text { Muslim }\end{array}$} & \multicolumn{1}{c}{ Frekuensi } & \multicolumn{1}{c}{ Persentase } \\
No & \multicolumn{1}{c}{ Ma } & 100 & 90,9 \\
\hline 1 & Ya & 10 & 9,1 \\
& Tidak & 110 & 100,0 \\
\hline
\end{tabular}

Berdasarkan data pada Tabel dapat diketahui bahwa jumlah responden sebanyak 110 pengusaha. 90,9\%Pengusaha Muslim telah melakukan kerjasama dengan pengusaha muslim. Dan hanya 9,1\% yang tidak melakukan kerjasama dengan pengusaha muslim. Dari persentase diatas terlihat bahwa kerjasama sesame muslim adalah hal yang penting untuk dilakukan dalam rangka menunjang kegiatan usaha serta mempererat hubungan silaturahmi. Selain hal tersebut, sesama muslim adalah saudara sehingga sangat wajar jika kita saling mengunjungi untuk keperluan berwirausaha sekaligus saling silaturahmi 
Mei Sumarni, Shinta Wahyu Hati

Muslimpreneur Berdasarkan Infaq

Tabel 10. Berdasarkan Infaq

\begin{tabular}{llcc}
\hline No & Infaq & Frekuensi & Persentase \\
\hline 1 & Ya & 110 & 100 \\
2 & Tidak & 0 & 0 \\
& Total & 110 & 100,0 \\
\hline
\end{tabular}

Berdasarkan data pada Tabel 10 dapat diketahui bahwa jumlah responden sebanyak 110 pengusaha. Keseluruhan pengusaha Muslim mengatakan selalu menyisihkan sebagian keuntungan untuk infaq. Karena dari 110 responden mengatakan memang infaq adalah hak dari sodara sodara kita yang ada diluar, sehingga memnag wajib untuk dikeluarkan. Dasarnya ada pada Al-Qur"an Surat Al-An"am ayat 160 dimana Allah menjanjikan balasan 10 kali lipat bagi mereka yang mau berbuat baik (bersedekah adalah salah satu perbuatan baik:"Barangsiapa membawa amal yang baik maka baginya (pahala) sepuluh kali lipat amalnya; dan barangsiapa yang membawa perbuatan yang jahat maka dia tidak diberi pembalasan melainkan seimbang dengan kejahatannya, sedang mereka sedikitpun tidak dianiaya (dirugikan)" Q.S Al-An"am (6) : 160

\section{Hasil Analisis Faktor Konfirmatori}

Tabel 11. KMO and Bartlett's Test

\begin{tabular}{|c|c|c|}
\hline Kaiser-meyer-Olkin & Sampling Adequacy & 633 \\
\hline Approx. Chi-Square & & 80,364 \\
\hline Bartllestt's Test Of & & \\
\hline Sphericity & $\mathrm{df}$ & 10 \\
\hline & sig. & ,000 \\
\hline
\end{tabular}

Berdasarkan Tabel 11, dapat dilihat bahwa angka KMO dan Bartlett Test adalah 0,633 $(>0,5)$ dengan tingkat signifikasi 0,000. Artinya sampel sudah memadai untuk dilakukan analisis lebih lanjut atau 63,3\% variansi dapat dijelaskan oleh faktor tersebut. Maka dari itu semua faktor indikator dapat dianalisis lebih lanjut. Analisis selanjutnya adalah dengan memeriksa Measure of Sampling Adequacy (MSA). Nilai MSA pada uji validitas tahap 1 dapat dilihat pada tabel berikut:

Tabel 12. Measure of Sampling Adequacy (MSA)

\begin{tabular}{cc}
\hline Indikator & Measure of Sampling Adequacy (MSA) \\
\hline Total X1 & 0,569 \\
Total X2 & 0,756 \\
Total X3 & 0,720 \\
Total X4 & 0,838 \\
Total Y & 0,970 \\
\hline
\end{tabular}

88 | IQTISHODUNA Vol. 15 No. 1 Tahun 2019

http://ejournal.uin-malang.ac.id/index.php/ekonomi 
Faktor-Faktor Yang Mempengaruhi Kinerja Usaha...

Communalities adalah total variance yang dijelaskan oleh faktor yang diekstrak. Pada analisis faktor konfirmatori yang diekstrak hanyalah common variance, sehingga tidak salah jika nilai common variance kurang dari satu. Hal ini dikarenakan common variance berasal dari total variance dikurangi specific variance dan error variance. Berikut disajikan output SPSS versi 20.0 terhadap communalities.

Tabel 13. Communalities

\begin{tabular}{ccc}
\hline & Intial & Extraction \\
\hline Total X1 & 1,000 &, 748 \\
Total X2 & 1,000 &, 544 \\
Total X3 & 1,000 &, 600 \\
Total X4 & 1,000 &, 355 \\
Total Y & 1,000 &, 839 \\
\hline
\end{tabular}

Indikator Produksi $\left(\mathrm{X}_{1}\right)$ angkanya adalah 0,748 hal ini menunjukkan bahwa $74,8 \%$ varians dari indikator produksi bisa dijelaskan oleh faktor yang terbentuk.

Indikator Pemasaran ( $\left.\mathrm{X}_{2}\right)$ angkanya adalah 0,544 hal ini menunjukkan bahwa sekitar $54,4 \%$ varians dari indicator pemasaran $\left(\mathrm{X}_{2}\right)$ bisa dijelaskan oleh faktor yang terbentuk.

Indikator Keuangan ( $\left.\mathrm{X}_{3}\right)$ angkanya adalah 0,600 hal ini menunjukkan bahwa sekitar $60 \%$ varians dari indicator keuangan $\left(\mathrm{X}_{3}\right)$ bisa dijelaskan oleh faktor terbentuk.

Indikator SDM ( $\left.\mathrm{X}_{4}\right)$ angkanya adalah 0,355 hal ini menunjukkan bahwa sekitar 35,5\% varians dari indicator SDM (X $\left.\mathrm{X}_{4}\right)$ bisa dijelaskan oleh faktor pembentuk.

Berdasarkan output tersebut dapat dilihat bahwa terdapat 4 variabel yang dimasukkan kedalam analisis faktor yaitu Produksi $\left(\mathrm{X}_{1}\right)$, Pemasaran $\left(\mathrm{X}_{2}\right)$, Keuangan $\left(\mathrm{X}_{3}\right)$, dan SDM $\left(\mathrm{X}_{4}\right)$. Dan terlihat juga terdapat 4 variabel dimasukkan kedalam analisis konfirmatori. Dilihat dari nilai eigen yang lebih dari $1(>1)$ terdapat 4 faktor yang terbentuk. Hal ini berarti 4 faktor yang digunakan penulis sebelumnya telah membangun instrument pada penelitian ini, telah diekstrak atau direduksi menjadi 4 faktor. 
Mei Sumarni, Shinta Wahyu Hati

Tabel 14. Total Variance Explained

\begin{tabular}{|c|c|c|c|c|c|c|}
\hline \multirow[b]{2}{*}{$\begin{array}{r}\text { Compon } \\
\text { ent }\end{array}$} & \multirow{2}{*}{\multicolumn{2}{|c|}{ Total \% of Variance }} & nvalues & \multicolumn{3}{|c|}{$\begin{array}{l}\text { Extraction Sums Of Squared } \\
\text { loadings }\end{array}$} \\
\hline & & & Cumulative & Total & $\begin{array}{c}\% \text { of } \\
\text { Variance }\end{array}$ & $\begin{array}{l}\text { Cumulati } \\
\text { ve }\end{array}$ \\
\hline 1 & 2,050 & 40,992 & 40,992 & 2,050 & 40,992 & 40,992 \\
\hline 2 & 1,037 & 20,736 & 61,729 & 1,037 & 20,736 & 61,729 \\
\hline 3 & 889 & 17,787 & 79,516 & & & \\
\hline 4 & ,628 & 12,562 & 92,078 & & & \\
\hline 5 & ,396 & 7,922 & 100,000 & & & \\
\hline
\end{tabular}

Tabel 15. Component Matrix

\begin{tabular}{lrr} 
& \multicolumn{3}{c}{ Component } \\
& $\mathbf{2}$ & \multicolumn{2}{c}{$\mathbf{2}$} \\
\hline Total X1 &, 853 &, 226 \\
Total X2 &, 741 &, 394 \\
Total X3 &, 624 &, 064 \\
Total X4 &, 593 &, 898 \\
Total Y &, 181 & \\
\hline
\end{tabular}

Pada tabel 15 disajikan angka-angka yang merupakan faktor loading atau besaran korelasi antara suatu indicator dengan variabel 1, 2, 3 dan 4 terlihat semua indicator sudah diatas 0,5. Maka indicator tersebut dapat masuk kedalam variabel nya.

Tabel 16. Rotated Component Matrix

\begin{tabular}{|l|r|r|}
\multirow{2}{*}{} & \multicolumn{3}{|c|}{ Component } \\
\cline { 2 - 3 } & 1 & \multicolumn{2}{|c|}{2} \\
\hline Total X1 &, 885 &, 023 \\
Total X2 &, 703 &, 326 \\
Total X3 &, 672 &, 304 \\
Total X4 &, 578 &, 145 \\
Total Y &, 055 &, 914 \\
\hline
\end{tabular}

Berdasarkan Tabel 16 dapat dijelaskan satu persatu indikator akan masuk ke faktor atau variabel nama, sebagai berikut: Produksi $\left(\mathrm{X}_{1}\right)$, faktor loading yang paling besar berada pada faktor 1 dengan korelasi sebsar 0,885. Untuk faktor produksi berpengaruh positif terhadap kinerja usaha Muslimpreneur di Kota Batam; Pemasaran ( $\mathrm{X}_{2}$ ), faktor loading dengan korelasi 0,703 . Hal ini berarti pemasaran berada pada faktor 2; Keuangan $\left(\mathrm{X}_{3}\right)$, faktor loading dengan korelasi 0,672 . Hal ini berarti keuangan berada pada faktor 3 ; 
Faktor-Faktor Yang Mempengaruhi Kinerja Usaha...

SDM $\left(\mathrm{X}_{4}\right)$, faktor loading dengan korelasi 0,578. Hal ini berarti SDM berada pada faktor 4 .

\section{Pembahasan}

\section{Pengaruh Variabel Produksi $\left(\mathrm{X}_{1}\right)$ terhadap kinerja usaha Muslipreneur (Y)}

Produksi memiliki dampak positif terhadap kinerja usaha Hal ini berdasarkan pada penelitian yang telah dilakukan, bahwa faktor produksi berpengaruh terhadap kinerja usaha Muslimpreneur. Hal ini disebabkan karena benar dengan adanya produksi yang sangat berpengaruh terhadap kinerja usaha yang ada di Kota Batam. Sehingga dapat dikatakan faktor produksi memiliki posisi yang sangat penting dalam menjalankan usaha, terutama Muslimpreneur di Kota Batam saat ini.

Penelitian ini dilakukan hanya di Kota Batam, pada setiap usaha faktor di item pertanyaan yang paling dominan yaitu produksi. Penelitian ini sesuai dengan peneliti terdahulu oleh M-Said Oukil (2013). Pada penelitian sebelumnya disebutkan faktor produksi sangat berpengaruh terhadap kinerja usaha seorang Muslimpreneur. Karena Produksi yang baik akan memberikan hasil produk yang baik dan bagus kualitasnya, sehingga akan mempengaruhi penjualan, kepercayaan customer. Loyalitas customer dan lainnya.

Berdasarkan Component Matrix terlihat total $\mathrm{X}_{1}$ jumlah total nya adalah 0,853 . Nilai tersebut sudah jauh diatas nilai maksimum 0,5 . sehingga terlihat bahwa Produksi berpengaruh terhadap kinerja usaha Muslimpreneur di Kota Batam. Pada item pertanyaan yang terdapat pada faktor pertama Produksi terlihat yang memiliki presentase tertinggi adalah item pertanyaan ke empat yaitu dengan pertanyaan kegiatan produksi memiliki nilai ibadah kepada Allah, mean sebesar 4,69.

Dari 110 responden 34 menjawab setuju, dan 76 menjawab sangat setuju. Karena benar kegiatan produksi adalah kegiatan yang penting karena produksi adalah hal mendasar. Dan sangat baik jika kegiatan tersebut memiliki nilai nilai ibadah kepada Allah. Sehingga dalam menjalankannya kita tidak hanya mendapatkan keuntungan secara materi tetapi juga mendapatkan keuangtungan berupa keridhoan dari Allah SWT. Dijelaskan "dan aku tidak menciptakan jin dan manusia melainkan supaya mereka mengabdi kepada-Ku." (Q.s. Al-Dzariyat: 56). Selain hal tersebut terdapat prinsip agar pekerjaan dunia kita memiliki nilai ibadah di sisi allah ta"ala, sehingga tidak sia-sia apa yang kita lakukan, yaitu dengan cara yang halal; dengan cara yang jujur, tidak dzalim dan bijaksana; dengan tulus ikhlas; dengan tetap mementingkan agama. 
Mei Sumarni, Shinta Wahyu Hati

Dengan pembuktian dari Component Matrix dengan melihat Total $\mathrm{X}_{1}$ dengan jumlah 0,853 , nilai tersebut sudah jauh diatas nilai maksimum 0,5 dan dengan penjelasan Al-Quran serta hadist membuktikan faktor produksi berpengaruh terhadap kinerja usaha Muslimpreneur di Kota Batam.

\section{Pengaruh Variabel Pemasaran $\left(\mathrm{X}_{2}\right)$ terhadap kinerja usaha Muslipreneur (Y)}

Berdasarkan Component Matrix total $\mathrm{X}_{2}$ pemasaran 0,71 nilai yang jauh dari ketetuan 0,5. Jika kita berpatokan pada component sudah jelas pemasaran masuk kedalam faktor Kinerja usaha Muslipreneur. Kita meneliti dan membandingkan dengan penelitian sebelumnya. Hal ini berdasarkan pada penelitian yang telah dilakukan, bahwa faktor pemasaran berpengaruh terhadap kinerja usaha Muslimpreneur. Sehingga dapat dikatakan faktor pemasaran memiliki posisi yang sangat penting dalam menjalankan usaha, terutama Muslimpreneur di Kota Batam saat ini. Penelitian ini dilakukan hanya di Kota Batam, yang mana setiap usaha faktor yang paling dominan selanjutnya yaitu faktor pemasaran.

Penelitian terdahulu Junaidi (2012) menyebutkan pemasaran adalah hal penting yang juga berpengaruh terhadap kinerja usaha seorang Muslimpreneur. Karena pemasaran adalah bagian pengenalan produk yang kita miliki kepada klayak ramai, sehingga dengan pemasaran yang baik, sesuai syariat yang telah ditetapkan tentu akan menghasilkan produk yang luar biasa serta kwalitas dan akan mempengaruhi loyalitas dari customer.

Selain didasarkan pada hasil component matrix, hasil penelitian terdahulu dalam Al-Quran dijelaskan bahwa pentingnya pemsaran dalam islam. Menurut prinsip syariah, kegiatan pemasaran harus dilandasi semangat beribadah kepada Tuhan Sang Maha Pencipta, berusaha semaksimal mungkin untuk kesejahteraan bersama, bukan untuk kepentingan golongan apalagi kepentingan sendiri.

Islam agama yang sangat luar biasa, islam agama yang lengkap, yang berarti mengurusi semua hal dalam hidup manusia. Islam agama yang mampu menyeimbangkan dunia dan akhirat; antara hablum minallah (hubungan dengan Allah) dan hablum minannas (hubungan sesama manusia). Ajaran Islam lengkap karena Islam agama terakhir sehingga harus mampu memecahkan berbagai masalah besar manusia. Rasulullah Shallallahu „alaihi wa sallam telah mengajarkan pada umatnya untuk berdagang dengan menjunjung tinggi etika keislaman. 
Faktor-Faktor Yang Mempengaruhi Kinerja Usaha...

\section{Pengaruh Variabel Keuangan $\left(\mathrm{X}_{3}\right)$ terhadap Kinerja Usaha Muslipreneur (Y)}

Faktor keuangan berpengaruh terhadap kinerja usaha Muslimpreneur. Sehingga dapat dikatakan faktor pemasaran memiliki posisi yang sangat penting dalam menjalankan usaha, terutama Muslimpreneur di Kota Batam saat ini. Pada penelitian terdahulu oleh Rahma (2013) disebutkan bahwa keuangan berpengaruh secara signifikan terhadap kinerja usaha sebuah wirausaha. Berdasarkan hasil Component Matrix disebutkan keuangan memiliki hasil 0,624. Nilai tersebut melebihi batas 0,5 sehingga keuangan masuk dalam faktor yang mempengaruhi kinerja usaha muslimpreneur di Kota Batam.

Keuangan dijelaskan oleh David (2011) adalah kondisi keuangan dianggap sebagai salah satu ukuran terbaik untuk posisi yang kompetitif. Menentukan ukuran kekuatan dan kelemahan keuangan suatu oranisasi sangat penting dalam sebuah kegiatan usaha. Sedangkan menurut Ridwan (2003) keuangan adalah ilmu dan seni yang mengelola keuangan yang mempengaruhi kehidupan setiap orang atau individu dan setiap organisasi. Landasan teori yang sesuai Sruktur keuangan Islam sangat kuat bersumber dari al-Qur"an dan sunnah, serta penafsiran terhadab sumber-sumber wahyu ini oleh para ulama.

Selama tiga dasawarsa terakhir, struktur keuangan Islam telah tampil sebagai salah satu implementasi modern dalam sistem hukum Islam yang paling penring dan berhasil, dan sebagai uji coba bagi pembaruan dan perkembangan hukum Islam pada masa datang. Meskipun demikian, keuanagn Islam tetap menimbulkan berbagai kesalahpahaman dikalangan muslim sendiri sekaligus kalangan non-Muslim. Keungan Islam bukanlah temuan dari gerakan politik eksterm Islam abad ini, namun bersumber dari perintah yang ada dalam Al-Qur"an dan Sunnah Nabi Muhammad. Untuk mudah memahaminya, cukup pahami dasar akad seperti bagi hasil, jual beli, sewa, kerjasama, penitipan, dan sebagainya. Imam menggambarkan prinsip dasar keuangan Syariah sebagai berikut Keadian, Maslahah, Zakat, Bebas dari Riba, Garar dan Bebas dari hal yang tidak sah. Dengan melihat item pertanyaan akan sangat sesuai jika component Keuangan masuk dalam salah satu faktor Kinerja Usaha seorang Muslimpreneur.

\section{Pengaruh Variabel Sumber Daya Manusia $\left(\mathrm{X}_{4}\right)$ terhadap Kinerja usaha Muslipreneur (Y)}

Hal ini berdasarkan pada penelitian yang telah dilakukan, bahwa faktor Sumber daya manusia berpengaruh terhadap kinerja usaha Muslimpreneur. 
Mei Sumarni, Shinta Wahyu Hati

Hal ini disebabkan karena hasil data menunjukkan sumber daya manusia sangat berpengaruh positif terhadap kinerja usaha yang ada di Kota Batam. Sehingga dapat dikatakan faktor sumber daya manusia memiliki posisi yang sangat penting dalam menjalankan usaha, terutama Muslimpreneur di Kota Batam saat ini. Berdasarkan component Matrix disebutkan jumlah hasil untuk Sumber Daya Manusia 0,59. Nilai yang cukup besar dan masuk sebagai salah satu faktor dalam kinerja usaha seorang Muslimpreneur.

Mathis dan Jacson (2006) menekankan bahwa sumber daya manusia adalah rancangan sistem formal yang memastikan aplikasi bakat manusia secara efektif dan efesien guna mencapai tujuan organisasi. Dijelaskan kembali oleh Dessler (2014) Manajemen sumber daya manusia adalah kebijakan dan praktek di dalam menggerakan sumber daya manusia atau aspekaspek terkait posisi manajemen di dalam sumber daya manusia yang mencakup kegiatan perekrutan, penyaringan, pelatihan, pemberian penghargaan dan penilaian

\section{KESIMPULAN}

Faktor-faktor yang dipertimbangkan seorang pengusaha muslim di Kota Batam terdapat 4 faktor diantaranya faktor Sumber daya manusia, Pemasaran, Keuangan, dan Produksi. Adapun dimensi pembentuk dari setiap faktor yaitu: Produksi, terdiri dari tipe produk memenuhi prinsip-prinsip Islam dalam produksi dan menghasilkan produk etis; Pemasaran, berhubungan dengan tidak terlibat dengan transaksi yang dilarang oleh Islam, iklan yang benar, jelas, dan transparan, kembalinya produk diperbolehkan dengan alasan yang tepat, dan persaingan bisnis; Keuangan, berhubungan dengan mematuhi prinsip-prinsip dasar keuangan Islam,biaya hanya untuk tujuan halal berdasarkan prinsip-prinsip darurriyat; Sumber daya Manusia, berhubungan dengan peresmian kerja, upah dan gaji, hubungan atau relasi.

Dari faktor-faktor yang terbentuk, faktor yang paling dominan dipertimbangkan pengusaha muslim dalam menentukan kinerja usaha adalah faktor Sumber daya manusia dan produksi dengan nilai Varians 0,23\% dan $1,45 \%$, hal ini terkait adanya kualitas sumber daya manusia dan produksi guna peningkatan kinerja usaha sekaligus peningkatan omset perusahaan.

Sebaiknya para pengusaha memperhatikan faktor-faktor apa saja yang dipertimbangkan pengusaha dalam menentukan kinerja usaha. Faktor-faktor yang perlu diperhatikan yaitu faktor pemasaran,dan keuangan. Faktor dominan yang harus diperhatikan adalah faktor Sumber daya manusia dan produksi. Karena faktor SDM dan produksi merupakan faktor penting yang 
Faktor-Faktor Yang Mempengaruhi Kinerja Usaha...

dapat meningkatkan kinerja usaha seorang Muslimprenenur dalam menjalankan usahanya.

\section{DAFTAR PUSTAKA}

Abdillah Junaidi. 2012. Fikih Pemasaran.Vol.5, No. 1.Februari 2012. 38.

David, F. R. 2011. Strategic Manajemen. (13thed). New Jersey: Pearson Education, Inc

Dessler, Gary. 2014. Manajemen Sumber Daya Manusia. Jakarta. Prehalindo.

Faizal, P.R.M. A.A.M. Ridhwan, and A.W.Kalsom. 2013. The Entrepreneur Characteristic From Al-Quran and Hadist. International Journal of Trade, Economics and Finance. Vol. 4. No. 4. August.

Hati, S. W. 2015. Analisis Profitabilitas Dalam menilai Kinerja Keuangan UMKM Jasa Studio Kita Peserta Program Mahasiswa Wirausaha (PMW) Politeknik Negeri Batam. Iqtishoduna, Jurnal Ekonomi dan Bisnis Islam. Vol.11 No. 1 tahun 2015. 3

Hasibuan, Malayu S.P. 2010. Manajemen Sumber Daya Manusia. Jakarta: PT. Bumi Aksara

Heflin, Frinces Z. 2010. Pentingnya Profesi Wirausaha di Indonesia. Jurnal Ekonomi \& Pendidikan, volume 7 nomor 1,

https: //ekbis.sindonews.com//entrepreneur-muda-ini-tarik perhatian Jokowi. 2015

https://www.batamnews.co.id/ batam-dan-hegemoni-singapura.html 2016.

Kotler, Philip dan Gary Amstrong. 2008. Prinsip-Prinsip Pemasaran. Jilid 1 dan 2. edisi Keduabelas. Erlangga. Jakarta.

Mangkunegara, Anwar Prabu. 2010. Manajemen Sumber daya Manusiaperusahaan. Bandung. PT Remaja Rosdakarya.

Mathis, Robert L. John H. Jackson. 2006. Human Resource Management. edisi 10, Jakarta. Salemba Empat.

Mohd Faizal 2013. The Characteristics Of Muslimpreneurs from the view of Muslim. Scholars and Academician, 40

M-Said Oukil. 2013. Entrepreneurship and Entrepreneur in context. Journal of Islam and human advanced reaserch.

Mongid, Abdul., Notodihardjo, Soegeng. 2010. Pengembangan daya saing UMKM Di malaysia dan singapura: sebuah komparasi. Jurnal Keuangan dan Perbankan, Vol.15, No.2 Mei 2011, hlm. 243-253. Terakreditasi SK. No. 64a/DIKTI/Kep/2010

Muhammad, Anwar. 2014. Pengantar Kewirausahaan Teori dan Aplikasi. Ed. 1. Jakarta: Prenadamedia Group. 
Mei Sumarni, Shinta Wahyu Hati

Sugiyono. 2011. Metode Penelitian Kuantitaif, Kualitatif dan $R \&$ D. Bandung. Alfabeta

Sunantri, Yudi., Toni Ari Wibowo. 2010. Analisis Pengaruh Kunjungan Wisatawan Yang Menjadikan Batam Sebagai Kawasan Pariwisata Mice. Program Studi Manajamen Perhotelan, Fakultas Ekonomi Universitas Internasional Batam.

Suryani. 2012. Pendekatan Karakteristik Wirausaha Sukses: Jakarta. Salemba Empat

Rameli, MF. Aziz.MR. Wahab K. Amin.SM. 2015 The Characteristics of Muslimpreneurs from the view of Muslim Scholars and Academician. International Journal of Teaching \& Education (IJOTE). Vol II No. 2

Ridwan Sundjaja. \& Barlian Inge. 2003. Manajemen Keuangan. edisi ke lima, Literata Lintas Media, Jakarta.

Rahma, W. 2013. Kewirausahaan dalam Perspektif Bisnis Syari'ah.23

Zimmerer, T. W., Scarborough, N. M., \& Wilson, D. 2008. Kewirausahaan dan Manajemen Usaha Kecil, Edisi 5 Buku 1. Jakarta. Salemba Empat. 